\title{
Short communication: Heritability of gross feed efficiency and associations with yield, intake, residual intake, body weight, and body condition score in 11 commercial Pennsylvania tie stalls
}

\author{
J. E. Vallimont, ${ }^{\star}$ C. D. Dechow, ${ }^{\star 1}$ J. M. Daubert, ${ }^{\star}$ M. W. Dekleva, ${ }^{\star}$ J. W. Blum,† C. M. Barlieb, ${ }^{\star}$ W. Liu, ${ }^{\star}$ \\ G. A. Varga, ${ }^{\star}$ A. J. Heinrichs,${ }^{*}$ and C. R. Baumrucker ${ }^{\star}$ \\ *Department of Dairy and Animal Science, The Pennsylvania State University, University Park 16802 \\ †Veterinary Physiology, Vetsuisse Faculty, University of Bern, 3012 Bern, Switzerland
}

\section{ABSTRACT}

The objectives of this study were to calculate the heritability of feed efficiency and residual feed intake, and examine the relationships between feed efficiency and other traits of productive and economic importance. Intake and body measurement data were collected monthly on 970 cows in 11 tie-stall herds for 6 consecutive mo. Measures of efficiency for this study were: dry matter intake efficiency (DMIE), defined as 305-d fat-corrected milk (FCM)/305-d DMI, net energy for lactation efficiency $\left(\mathrm{NE}_{\mathrm{L}} \mathrm{E}\right)$, defined as 305-d FCM/05-d $\mathrm{NE}_{\mathrm{L}}$ intake, and crude protein efficiency (CPE), defined as 305-d true protein yield/305-d CP intake. Residual feed intake (RFI) was calculated by regressing daily DMI on daily milk, fat, and protein yields, body weight (BW), daily body condition score (BCS) gain or loss, the interaction between $\mathrm{BW}$ and $\mathrm{BCS}$ gain or loss, and days in milk (DIM). Data were analyzed with 3- and 4-trait animal models and included 305-d FCM or protein yield, $\mathrm{DM}, \mathrm{NE}_{\mathrm{L}}$, or $\mathrm{CP}$ intake, $\mathrm{BW}, \mathrm{BCS}$, BCS change between DIM 1 and 60, milk urea nitrogen, somatic cell score, RFI, or an alternative efficiency measure. Data were analyzed with and without significant covariates for BCS and BCS change between DIM 1 and 60. The average DMIE, $\mathrm{NE}_{\mathrm{L}} \mathrm{E}$, and $\mathrm{CPE}$ were $1.61,0.98$, and 0.32 , respectively. Heritability of gross feed efficiency was 0.14 for DMIE, 0.18 for $\mathrm{NE}_{\mathrm{L}} \mathrm{E}$, and 0.21 for CPE, and heritability of RFI was 0.01 . Body weight and BCS had high and negative correlations with the efficiency traits $(-0.64$ to -0.70$)$, indicating that larger and fatter cows were less feed efficient than smaller and thinner cows. When BCS covariates were included in the model, cows identified as being highly efficient produced $2.3 \mathrm{~kg} / \mathrm{d}$ less FCM in early lactation due to less early lactation loss of BCS. Results from this study suggest that selection for higher yield and

Received October 1, 2010.

Accepted December 14, 2010.

${ }^{1}$ Corresponding author: cdechow@psu.edu lower BW will increase feed efficiency, and that body tissue mobilization should be considered.

Key words: feed efficiency, heritability, genetic correlation, residual feed intake

\section{Short Communication}

Profitability on dairy farms is limited by feed costs, the single largest expense of dairy production. Herds that control feed costs will likely experience an improvement in profitability. Improving herd feed efficiency without sacrificing production, reproduction, or health may help to achieve this goal.

Several studies (Korver, 1988; Veerkamp and Emmans, 1995; Veerkamp, 1998) have reviewed the basis for genetic variation in feed utilization in dairy cattle and report potential to increase efficiency through genetic selection. Genetic correlation estimates between gross feed efficiency (ECM yield/DMI) and ECM yield range from 0.75 to 0.95 (Korver, 1988; Van Arendonk et al., 1991). Genetic selection has increased the level of body tissue mobilization in early lactation (Dechow et al., 2002), which may inflate estimates of gains in gross efficiency if the contribution of energy from body tissue mobilization to milk production is not considered. For this reason, measures of residual feed intake (RFI) or feed efficiency that account for body tissue mobilization may be of greater interest than gross feed efficiency.

Evidence from some studies suggests that some variation in residual intake is under genetic control (Veerkamp, 1998; Coleman et al., 2010); however, Ngwerume and Mao (1992) reported a heritability value of only 0.016 for residual energy intake in a study of 247 Holstein cows. Van Arendonk et al. (1991) reported a heritability estimate for gross efficiency of 0.37 , whereas heritability for residual intake was 0.19.

The objectives of this study were to calculate the heritability of feed efficiency and RFI, and to examine the relationships between feed efficiency and other traits of productive and economic importance.

Intake and body measurement data were collected monthly on 970 cows in 11 tie-stall herds for 6 consecu- 
tive mo. Details of feeding management, data collection, and generation of yield, BW, intake, MUN, and SCS records were previously published (Vallimont et al., 2010). Body condition score data was evaluated differently in the current study. In the previous study, fitting random regression models for feed intake was not successful and these models were not given further consideration for any of the traits. Due to the fact that the effect of body tissue mobilization on feed efficiency was of interest in this study, BCS was evaluated with a random regression model. The model was identical to the test-day model in Vallimont et al. (2010), except that linear Legendre polynomials for the animal effect and quadratic Legendre polynomials for the within lactation permanent environmental effects were included.

Measures of efficiency for this study were: DMI efficiency (DMIE), defined as 305-d FCM/305-d DMI, $\mathrm{NE}_{\mathrm{L}}$ efficiency $\left(\mathbf{N E}_{\mathbf{L}} \mathbf{E}\right)$, defined as 305-d FCM/305-d $\mathrm{NE}_{\mathrm{L}}$ intake, and CP efficiency (CPE), defined as 305-d true protein yield/305-d CP intake. Residual feed intake was calculated by regressing daily DMI on daily milk, fat, and protein yields, BW, daily BCS gain or loss, the interaction between BW and BCS gain or loss, and DIM. Regressions were performed within herd and lactation number to account for potential differences in accuracy of intake records across herds and to account for differences in growth and lactation curves for different lactations. Previous researchers (Van Arendonk et al., 1991) have not considered stage of lactation, but residuals did not achieve a random pattern without including DIM in the current study. Daily RFI were summed to create 305-d RFI.

Data were analyzed with 3- and 4-trait animal models in ASREML (Gilmour et al., 2006). All models for DMIE or $\mathrm{NE}_{\mathrm{L}} \mathrm{E}$ included 305-d FCM as a second trait. Additional traits added either 1 or 2 at a time included $\mathrm{BW}, \mathrm{DM}$ or $\mathrm{NE}_{\mathrm{L}}$ intake, BCS, BCS change between DIM 1 and $60\left(\mathbf{B C S C H}_{60}\right)$, MUN, SCS, RFI, or an alternative efficiency measure. Analyses of CPE were identical except that 305-d FCM was replaced by true protein yield and DMI was replaced by $\mathrm{CP}$ intake. Traits were analyzed with the following model:

$$
Y_{i j k l}=L_{i j}+H C C_{i k}+A_{i l}+P_{i l}+\varepsilon_{i j k l},
$$

where $Y$ is the lactation record for trait $i ; L$ is the fixed effect of lactation $j$ for trait $i$; $H C C$ is the fixed effect of herd-calving-cluster $k$ (Vallimont et al., 2010) for trait $i ; A$ is the random additive genetic effect of animal $l$ for trait $i ; P$ is the random permanent environmental effect across lactations for cow $l$ for trait $i$; and $\varepsilon$ is random error.
Data were analyzed with and without covariates for $\mathrm{BCS}$ and $\mathrm{BCSCH}_{60}$. The effect of including these significant covariates on EBV for feed efficiency was assessed with 2 methods. First, the rank correlation between EBV for efficiency with and without the covariables for sires with at least 10 daughters was calculated. Second, test-day records for yield and BCS (Vallimont et al., 2010) for the top and bottom 10 percent of cows for DMIE EBV were evaluated with the MIXED procedure of SAS. The model included fixed effects of herd test date, age at calving class, lactation number, and month of calving nested within EBV class (top 10 percent or bottom 10 percent). Random effects were cow and error. Least-squared-means were calculated for month of lactation within EBV class.

Average DMIE, $\mathrm{NE}_{\mathrm{L}} \mathrm{E}$, and $\mathrm{CPE}$ were 1.61, 0.98, and 0.32 , respectively. Dry matter intake efficiency was similar to values reported by Martinez et al. (2009) for cows on a $60 \%$ forage diet when their results were converted from $3.5 \%$ FCM to $4.0 \%$ FCM. The average $\mathrm{NE}_{\mathrm{L}} \mathrm{E}$ was slightly higher than older estimates from Custodio et al. (1983) and Hooven et al. (1972). Hooven et al. (1972) reported an average $\mathrm{NE}_{\mathrm{L}} \mathrm{E}$ for ten $30-\mathrm{d}$ segments of lactation and those ranged from 0.99 in early lactation to 0.65 in late lactation. That range was explained by body tissue mobilization inflating the efficiency measures during early lactation. In later lactation, the body tissue reserves had been depleted, thus, decreasing the efficiency value. The average CPE was similar to other studies that reported $\mathrm{N}$ efficiency. Custodio et al. (1983) reported $\mathrm{N}$ efficiencies of 0.28 and 0.24 in the first and second trimesters of lactation, respectively. More recently, Martinez et al. (2009) reported $\mathrm{N}$ efficiencies ranging from 0.32 to 0.36 .

Heritability estimates and genetic and phenotypic correlations for the 3 measures of feed efficiency and selected traits are reported in Table 1. Gross feed efficiency had heritability estimates ranging from 0.14 (DMIE) to 0.21 (CPE), which were lower than estimates for FCM (0.22) and protein yield (0.31). This contrasts with a review by Veerkamp and Emmans (1995), where they reported that the heritability of gross efficiency is often quite similar to the heritability of milk yield. The genetic correlations among the efficiency traits were $0.71 \pm 0.10$ between $\mathrm{NE}_{\mathrm{L}} \mathrm{E}$ and $\mathrm{CPE}, 0.70 \pm 0.12$ between DMIE and CPE, and 0.99 between $\mathrm{NE}_{\mathrm{L}} \mathrm{E}$ and DMIE (standard error was not estimable). This suggests that CPE may be a genetically different trait than other measures of efficiency.

The genetic correlation estimates of FCM with DMIE (0.87) and $\mathrm{NE}_{\mathrm{L}} \mathrm{E}$ (0.86) were both strong, as was the genetic correlation estimate of protein yield with $\mathrm{CPE}$ 
Table 1. Estimates of heritability $\left(\mathrm{h}^{2} ; \pm \mathrm{SE}\right)$ and genetic standard deviations $\left(\sigma_{\mathrm{a}}\right)$ for DMI efficiency (DMIE), $\mathrm{NE}_{\mathrm{L}}$ efficiency $\left(\mathrm{NE}_{\mathrm{L}} \mathrm{E}\right)$, and $\mathrm{CP}$ efficiency $(\mathrm{CPE})$, and genetic $\left(\mathrm{r}_{\mathrm{g}}\right)$ and phenotypic correlations $\left(\mathrm{r}_{\mathrm{p}}\right)$ of efficiency with yield, BW, BCS, MUN, SCS, BCS change from DIM 1 to $60\left(\mathrm{BCSCH}_{60}\right)$, intake, and residual feed intake

\begin{tabular}{|c|c|c|c|c|}
\hline Item & $\mathrm{h}^{2}$ & DMIE & $\mathrm{NE}_{\mathrm{L}} \mathrm{E}$ & CPE \\
\hline $\begin{array}{l}\operatorname{Mean}^{1} \\
\mathrm{~h}^{2} \\
\sigma_{\mathrm{a}}\end{array}$ & & $\begin{array}{c}1.61(0.26) \\
0.14 \pm 0.06 \\
0.08\end{array}$ & $\begin{array}{l}0.98(0.24) \\
0.18 \pm 0.06 \\
0.05\end{array}$ & $\begin{array}{c}0.32(0.06) \\
0.21 \pm 0.06 \\
0.02\end{array}$ \\
\hline $\begin{array}{l}\text { Yield }^{2} \\
\text { BW } \\
\text { BCS } \\
\text { MUN } \\
\text { SCS } \\
\text { BCSCH }_{60} \\
\text { Intake }^{4} \\
\text { Residual intake }\end{array}$ & $\begin{array}{l}0.22 \pm 0.04^{3} \\
0.59 \pm 0.09 \\
0.30 \pm 0.07 \\
0.57 \pm 0.06 \\
0.23 \pm 0.06 \\
0.03 \pm 0.04 \\
0.16 \pm 0.07 \\
0.01 \pm 0.05\end{array}$ & $\begin{array}{r}0.87 \pm 0.08 \\
-0.66 \pm 0.13 \\
-0.70 \pm 0.16 \\
-0.08 \pm 0.16 \\
-0.23 \pm 0.19 \\
0.91 \pm 0.55 \\
0.11 \pm 0.32 \\
-0.73 \pm 1.29\end{array}$ & $\begin{aligned} \mathrm{r}_{\mathrm{g}} \\
0.86 \pm 0.08 \\
-0.64 \pm 0.14 \\
-0.69 \pm 0.16 \\
-0.10 \pm 0.15 \\
-0.25 \pm 0.18 \\
0.91 \pm 0.54 \\
0.07 \pm 0.30 \\
-0.69 \pm 0.86\end{aligned}$ & $\begin{aligned} 0.90 & \pm 0.07 \\
-0.66 & \pm 0.13 \\
-0.64 & \pm 0.17 \\
-0.10 \pm 0.14 & \pm 0.17 \pm 0.17 \\
-0.17 & \pm 0.53 \\
1.05 & \pm 0.06 \\
0.06 & \pm 0.30\end{aligned}$ \\
\hline $\begin{array}{l}\text { Yield }^{2} \\
\text { BW } \\
\text { BCS } \\
\text { MUN } \\
\text { SCS } \\
\text { BCSCH }_{60} \\
\text { Intake } \\
\text { Residual intake }\end{array}$ & & $\begin{array}{r}0.87 \pm 0.08 \\
-0.20 \pm 0.03 \\
-0.35 \pm 0.03 \\
0.18 \pm 0.04 \\
-0.16 \pm 0.04 \\
0.37 \pm 0.03 \\
-0.28 \pm 0.03 \\
-0.53 \pm 0.02\end{array}$ & $\begin{aligned} \mathrm{r}_{\mathrm{p}} \\
0.79 \pm 0.01 \\
-0.20 \pm 0.03 \\
-0.36 \pm 0.03 \\
0.18 \pm 0.03 \\
-0.17 \pm 0.03 \\
0.37 \pm 0.03 \\
-0.28 \pm 0.03 \\
-0.53 \pm 0.03\end{aligned}$ & $\begin{aligned} 0.76 & \pm 0.01 \\
-0.17 & \pm 0.03 \\
-0.24 & \pm 0.03 \\
0.15 & \pm 0.03 \\
-0.13 & \pm 0.03 \\
0.26 & \pm 0.03 \\
-0.35 & \pm 0.03\end{aligned}$ \\
\hline
\end{tabular}

${ }^{1}$ Standard deviation in parentheses.

${ }^{2}$ Correlations of DMIE and $\mathrm{NE}_{\mathrm{L}} \mathrm{E}$ with $\mathrm{FCM}$, and correlations of $\mathrm{CPE}$ with protein yield.

${ }^{3}$ The heritability in the table is for FCM; $\mathrm{h}^{2}$ for milk protein is $0.30 \pm 0.05$.

${ }^{4}$ Individual heritabilities were $0.17,0.17$, and 0.15 for DMI, NE $\mathrm{I}$, and CPI, respectively; the reported heritability is the average. Correlations of DMI with DMIE, $\mathrm{NE}_{\mathrm{L}}$ intake with $\mathrm{NE}_{\mathrm{L}} \mathrm{E}$, and $\mathrm{CP}$ intake with CPE.

${ }^{5}$ Failed to converge to a positive definite solution.

(0.90). Body weight and BCS had strong and negative correlations with the efficiency traits $(-0.64$ to -0.70$)$, indicating that larger and fatter cows were less efficient than smaller and thinner cows. Genetic correlation es- timates of yield with RFI were not significantly different from 0. The genetic correlation between FCM and RFI was $-0.01 \pm 0.79$, whereas the genetic correlation between protein yield and RFI was $0.31 \pm 0.79$ (data

Table 2. Estimates of heritability $\left(\mathrm{h}^{2} ; \pm \mathrm{SE}\right)$ and genetic standard deviations $\left(\sigma_{\mathrm{a}}\right)$ for DMI efficiency (DMIE), $\mathrm{NE}_{\mathrm{L}}$ efficiency $\left(\mathrm{NE}_{\mathrm{L}} \mathrm{E}\right)$, and CP efficiency $(\mathrm{CPE})$, and genetic $\left(\mathrm{r}_{\mathrm{g}}\right)$ and phenotypic correlations $\left(\mathrm{r}_{\mathrm{p}}\right)$ of efficiency with yield, BW, and intake from analyses with BCS and BCS change from DIM 1 to $60\left(\mathrm{BCSCH}_{60}\right)$ included as covariates

\begin{tabular}{lcccr}
\hline Item & $\mathrm{h}^{2}$ & $\mathrm{DMIE}$ & $\mathrm{NE}_{\mathrm{L}} \mathrm{E}$ & \multicolumn{1}{c}{$\mathrm{CPE}$} \\
\hline $\mathrm{h}^{2}$ & & $0.16 \pm 0.05$ & $0.16 \pm 0.06$ & $0.21 \pm 0.06$ \\
$\sigma_{\mathrm{a}}$ & 0.07 & 0.05 & 0.02 \\
& & $\mathrm{r}_{\mathrm{g}}$ & \\
Yield $^{1}$ & $0.23 \pm 0.04^{2}$ & $0.86 \pm 0.08$ & $0.85 \pm 0.09$ & $0.88 \pm 0.07$ \\
$\mathrm{BW}$ & $0.56 \pm 0.09$ & $-0.44 \pm 0.16$ & $-0.43 \pm 0.16$ & $-0.48 \pm 0.14$ \\
Intake $^{3}$ & $0.17 \pm 0.07$ & - & $0.15 \pm 0.33$ & $0.06 \pm 0.30$ \\
& & & $\mathrm{r}_{\mathrm{p}}$ & \\
Yield $^{1}$ & & $0.91 \pm 0.09$ & $0.88 \pm 0.09$ & $1.08 \pm 0.21$ \\
BW $_{\text {Intake }}$ & & $-0.07 \pm 0.03$ & $-0.07 \pm 0.03$ & $-0.09 \pm 0.03$ \\
\hline
\end{tabular}

${ }^{1}$ Correlations of DMIE and $\mathrm{NE}_{\mathrm{L}} \mathrm{E}$ with FCM, and correlations of CPE with protein yield.

${ }^{2}$ The heritability in the table is for FCM; $\mathrm{h}^{2}$ for milk protein is $0.30 \pm 0.05$.

${ }^{3}$ Individual heritabilities were 0.17 and 0.16 for $\mathrm{NE}_{\mathrm{L}}$ intake and $\mathrm{CP}$ intake, respectively; the reported heritability is the average. The model with DMI failed to converge. Correlations of DMI with DMIE, $\mathrm{NE}_{\mathrm{L}}$ intake with $\mathrm{NE}_{\mathrm{L}} \mathrm{E}$, and $\mathrm{CP}$ intake with $\mathrm{CPE}$.

${ }^{4}$ Failed to converge to a positive definite solution. 


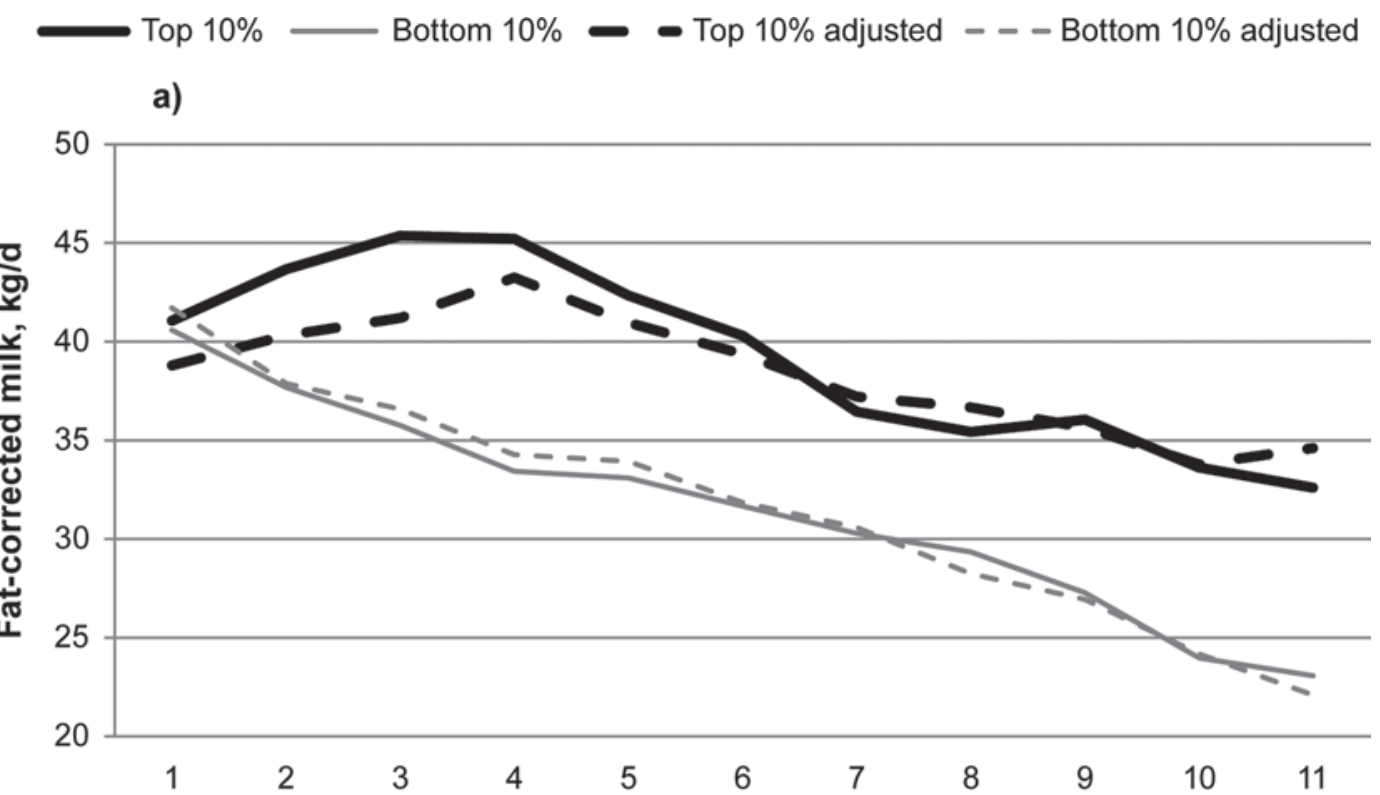

b)

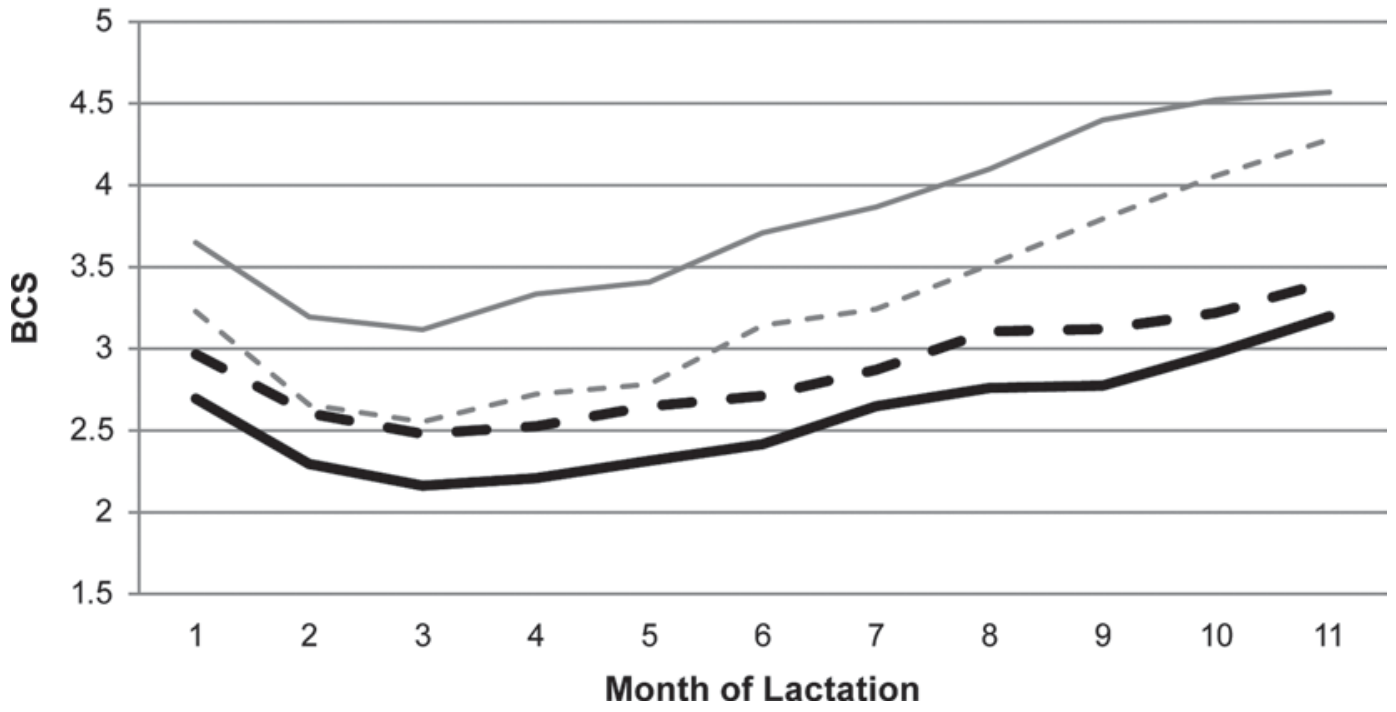

Figure 1. (a) The effect of adjustment for BCS and BCS change from DIM 1 to 60 on FCM yield from the top and bottom $10 \%$ of cows as ranked by DMI efficiency. (b) The effect of adjustment for BCS and BCS change from DIM 1 to 60 on BCS from the top and bottom 10\% of cows as ranked by DMI efficiency.

not shown). Body weight (0.59) and MUN (0.57) were estimated to be the most highly heritable traits. The heritability of BW was similar to results from Toshniwal et al. (2008) and the heritability of MUN was similar to results from Wood et al. (2003). Mitchell et al. (2005) reported lower heritabilities for MUN (0.15 to 0.22 ). Body condition score change from DIM 1 to 60 had low heritability (0.03), which agrees with previous studies reporting lower heritability for early lactation BCS loss than for average level of BCS across lactation (Berry et al., 2002; Dechow et al., 2002). Genetic correlation estimates of $\mathrm{BCSCH}_{60}$ with efficiency traits were high and unfavorable (0.91 to 1.05). Out-of-range values with ASREML have been previously reported by Gilmour and Thompson (2003). Although these correlations were accompanied by high standard errors ( 0.53 to 0.55 ), the high correlation between efficiency and $\mathrm{BCSCH}_{60}$ is not a favorable outcome and suggests that $\mathrm{BCS}$ and $\mathrm{BCSCH}_{60}$ should be accounted for when measuring efficiency.

Heritabilities for the intake traits were 0.17 for DMI, 0.17 for $\mathrm{NE}_{\mathrm{L}}$ intake, and 0.15 for $\mathrm{CP}$ intake. Genetic 
correlations between the intake and efficiency traits ranged from 0.06 to 0.11 . Although intake was the denominator in the efficiency calculations and might be expected to be negatively correlated with efficiency, the strong genetic correlation between intake and yield (Vallimont et al., 2010) likely created a neutral correlation. The phenotypic correlation between DMIE and DMI was negative (-0.28). Additionally, the partial genetic correlation between DMIE and DMI was -0.89 after accounting for the correlations of DMIE (0.87) and DMI (0.55, Vallimont et al., 2010) with FCM.

The phenotypic standard deviation for RFI was 405 $\mathrm{kg}$ per lactation compared with $775 \mathrm{~kg}$ per lactation for DMI. The heritability for residual feed intake was 0.01 , quite similar to the extremely low value reported by Ngwerume and Mao (1992). A review by Veerkamp and Emmans (1995) reported heritabilities for RFI that ranged from 0.14 to 0.32. Jensen et al. (1995) reported an even higher heritability for RFI in lactating cows, 0.69. It is not clear whether our lack of a strong genetic component to RFI was due to differences in estimating RFI that more completely accounted for genetic differences in the partitioning of nutrients, or if our method of data collection was too insensitive to allow capture of subtle genetic differences in RFI among animals. The correlations of RFI with DMIE and $\mathrm{NE}_{\mathrm{L}} \mathrm{E}$ were strong and in the anticipated direction (negative), but were associated with extreme standard errors.

Results from the analyses with covariates for BCS and $\mathrm{BCSCH}_{60}$ are presented in Table 2. These adjustments did not result in considerable changes to the heritabilities that were calculated without adjustments, nor were substantial changes observed for genetic correlations of FCM and protein yield with the efficiency traits. The adjustments decreased the unfavorable relationship between efficiency and BW to some extent because of the strong genetic correlation between BCS and BW (Vallimont et al., 2010).

The rank correlation of EBV for DMIE before and after adjustment for $\mathrm{BCS}$ and $\mathrm{BCSCH}_{60}$ was 0.91 , which was identical to that observed for $\mathrm{NE}_{\mathrm{L}} \mathrm{E}$ and lower than observed for CPE (0.96). This suggested that CPE was less influenced by body tissue mobilization in early lactation than were DMIE or $\mathrm{NE}_{\mathrm{L}} \mathrm{E}$. Figures $1 \mathrm{a}$ and $1 \mathrm{~b}$ illustrate the effects of adjusting for $\mathrm{BCS}$ and $\mathrm{BCSCH}_{60}$ on the type of cows identified as the top and bottom $10 \%$ for estimated DMIE breeding values. Minimal differences existed in the least squares means for the bottom $10 \%$ of cows for FCM with or without adjustment for BCS and $\mathrm{BCSCH}_{60}$. The biggest difference for $\mathrm{FCM}$ yield between the adjusted and unadjusted values came in early lactation for the group of cows in the top $10 \%$. During mo 1, FCM yield was decreased by $2.3 \mathrm{~kg} / \mathrm{d}$ when the data were adjusted for the BCS traits (Fig- ure 1a). This difference in FCM yield continued with similar magnitude until mo 4 when the difference began to decrease. Decreased early lactation yield likely represented a decrease in FCM supported by more extreme body tissue mobilization in the cows identified as high for DMIE when not adjusting for BCS and $\mathrm{BCSCH}_{60}$.

The difference between the BCS of top and bottom $10 \%$ of cows when ranked by estimated DMIE breeding values with unadjusted data was almost 1 whole BCS point (Figure 1b). After the BCS adjustments, differences in BCS between the top and bottom DMIE groups were minimal in early lactation; however, by the end of lactation, the difference had increased to almost 1 BCS point and less efficient cows gained more BCS in late lactation than did more efficient cows.

This study supported conclusions from previous research that gross feed efficiency has a strong genetic correlation with yield, and that gross efficiency is more heritable than RFI (Veerkamp and Emmans, 1995). Larger cows and cows with higher BCS were genetically inclined toward lower feed efficiency. Additionally, this study suggests that failure to account for body tissue mobilization will identify cows as efficient that are prone to early lactation BCS loss. Such selection would compromise cow health and reproductive performance and might not increase efficiency, because not all energy used to deposit body tissue is recovered when that tissue is mobilized (NRC, 2001). Adjustment for BCS and $\mathrm{BCSCH}_{60}$ suggested that the most efficient cows were those with high yield and that did not rapidly gain BCS in later lactation.

\section{ACKNOWLEDGMENTS}

This research was supported by CSREES-2008-34437-19335. The authors gratefully acknowledge the generosity of the 11 farms that participated in the trial. Andrew F. Read and Andrew S. Bell (Department of Biology, Penn State, University Park) are acknowledged for sharing their equipment. Kelly Crawford's (Huck Institutes, Penn State) assistance is also greatly appreciated.

\section{REFERENCES}

Berry, D. P., F. Buckley, P. Dillon, R. D. Evans, M. Rath, and R. F Veerkamp. 2002. Genetic parameters for level and change of body condition score and body weight in dairy cows. J. Dairy Sci. 85:2030-2039

Coleman, J., D. P. Berry, K. M. Pierce, A. Brennan, and B. Horan. 2010. Dry matter intake and feed efficiency profiles of 3 genotypes of Holstein-Friesian within pasture-based systems of milk production. J. Dairy Sci. 93:4318-4331.

Custodio, A. A., R. W. Blake, P. F. Dahm, T. C. Cartwright, G. T. Schelling, and C. E. Coppock. 1983. Relationships between measures of feed efficiency and transmitting ability for milk of Holstein cows. J. Dairy Sci. 66:1937-1946. 
Dechow, C. D., G. W. Rogers, and J. S. Clay. 2002. Heritability and correlations among body condition score loss, body condition score, production and reproductive performance. J. Dairy Sci. 85:3062-3070

Gilmour, A. R., B. J. Gogel, B. R. Cullis, and R. Thompson. 2006 ASREML User Guide. Release 2.0. VSN International Ltd., Hemel Hempstead, UK.

Gilmour, A. R., and R. Thompson. 2003. Options for estimating variance components in large mixed models. Pages 206-209 in Proc. 15th Conf. Assoc. Advance. Anim. Breed. Genet., Melbourne, Australia.

Hooven, N. W. Jr., R. H. Miller, and J. W. Smith. 1972. Relationships among whole- and part-lactation gross feed efficiency, feed consumption, and milk yield. J. Dairy Sci. 55:1113-1122.

Jensen, J., W. D. Hohenboken, P. Madsen, and B. B. Andersen. 1995. Sire X nutrition interactions and genetic parameters for energy intake, production, and efficiency of nutrient utilization in young bulls, heifers, and lactating cows. Acta. Agric. Scand. Sect. A. Animal Sci. 45:81-91.

Korver, S. 1988. Genetic aspects of food intake and feed efficiency in dairy cattle: A review. Livest. Prod. Sci. 20:1-13.

Martinez, C. M., Y.-H. Chung, V. A. Ishler, K. W. Bailey, and G. A. Varga. 2009. Effects of dietary forage level and monensin on lactation performance, digestibility and fecal excretion of nutrients, and efficiency of feed nitrogen utilization of Holstein dairy cows. J. Dairy Sci. 92:3211-3221

Mitchell, R. G., G. W. Rogers, C. D. Dechow, J. E. Vallimont, J. B. Cooper, U. Sander-Nielsen, and J. S. Clay. 2005. Milk urea nitrogen concentration: Heritability and genetic correlations with reproductive performance and disease. J. Dairy Sci. 88:4434-4440.
Ngwerume, F., and I. L. Mao. 1992. Estimation of residual energy intake for lactating cows using an animal model. J. Dairy Sci. $75: 2283-2287$

NRC. 2001. Nutrient Requirements of Dairy Cattle. Natl. Acad. Press, Washington, DC.

Toshniwal, J. K., C. D. Dechow, B. G. Cassell, J. A. D. R. N. Appuhamy, and G. A. Varga. 2008. Heritability of electronically recorded daily body weight and correlations with yield, dry matter intake, and body condition score. J. Dairy Sci. 91:3201-3210.

Vallimont, J. E., C. D. Dechow, J. M. Daubert, M. W. Dekleva, J. W. Blum, C. M. Barlieb, W. Liu, G. A. Varga, A. J. Heinrichs, and C. R. Baumrucker. 2010. Genetic parameters of feed intake, production, body weight, body condition score, and selected type traits of Holstein cows in commercial tie-stall barns. J. Dairy Sci. 93:4892-4901.

Van Arendonk, J. A. M., G. J. Nieuwhof, H. Vos, and S. Korver. 1991. Genetic aspects of feed intake and efficiency in lactating dairy heifers. Livest. Prod. Sci. 29:263-275.

Veerkamp, R. F. 1998. Selection for economic efficiency of dairy cattle using information on live weight and feed intake: A review. J. Dairy Sci. 81:1109-1119.

Veerkamp, R. F., and G. C. Emmans. 1995. Review: Sources of genetic variation in energetic efficiency of dairy cows. Livest. Prod. Sci. 44:87-97.

Wood, G. M., P. J. Boettcher, J. Jamrozik, G. B. Jansen, and D. F. Kelton. 2003. Estimation of genetic parameters for concentrations of milk urea nitrogen. J. Dairy Sci. 86:2462-2469. 